\title{
Effects of hunting camps on breeding grey-necked picathartes Picathartes oreas in south-east Nigeria
}

\author{
Fidelis Akunke Atuo, Samuel T. Ivande, Zingfa Wala \\ and Timothy J. O’ CONNELL
}

\begin{abstract}
The dependence of forest communities on bushmeat as a source of protein and income is a challenge to wildlife conservation in Sub-Saharan Africa. We investigated the use of caves and overhanging rocks as hunting camps and the consequences for breeding greynecked picathartes Picathartes oreas in the forests of Cross River in south-east Nigeria. We recorded 84 nesting colonies during guided and random searches. We found 14 (16.7\%) breeding sites that had been used as hunting camps, with evidence including fire stands, sleeping spots, cooking utensils and drying racks. Fire stands were the most frequently recorded evidence of camping and were found in 11 of the camps. At the 14 breeding sites only two nesting attempts were made by $P$. oreas during the survey. Thirtyseven nests (c. 95\%) recorded in hunting camps were empty and showed no evidence of ongoing or potential breeding activities, suggesting that the nests may have been abandoned. We attributed the low nesting attempt rate to disturbance caused by hunters, who also affected breeding success through direct removal of eggs and fledglings from nests. We encourage conservation education for the protection of $P$. oreas and other threatened species in the region and recommend strict enforcement of wildlife laws and disciplinary sanctions. Given the role of the forests of Cross River as a critical habitat for several endemic and threatened species, management efforts targeted at improving the integrity of the forest will benefit grey-necked picathartes and other avian species of conservation concern.
\end{abstract}

Keywords Bushmeat, caves, Cross River, grey-necked picathartes, hunting camps, Nigeria, overhanging rocks, Picathartes oreas

This paper contains supplementary material that can be found online at http://journals.cambridge.org

Fidelis AkUnke ATuo* (Corresponding author) and Timothy J. O'ConNell Department of Natural Resource Ecology and Management, Oklahoma State University, 74078, Stillwater, Oklahoma, USA. E-mail: fidelis.atuo@okstate.edu

Samuel T. Ivande and Zingfa Wala A. P. Leventis Ornithological Research Institute (APLORI), University of Jos, Nigeria

${ }^{*}$ Also at: A. P. Leventis Ornithological Research Institute (APLORI), University of Jos, Nigeria

Received 29 July 2012. Revision requested 11 January 2013.

Accepted 5 April 2013. First published online 26 March 2014.

\section{Introduction}

The decline of wildlife populations in Sub-Saharan Africa has been attributed to habitat loss as a result of agriculture and rural development, and hunting activities. Bushmeat hunting is an ancient and widespread cultural practice in Africa (Anadu et al., 1988; Wilkie \& Carpenter, 1999; Willcox \& Nambu, 2007), probably related to the close proximity of communities and wildlife habitats (Cordeiro et al., 2007). For example, the Okwangwo Division of Cross River National Park has two enclave communities (Okwa and Okwangwo) and 66 others located $<_{1} \mathrm{~km}$ from the forest (Ezebilo \& Mattsson, 2010). These communities meet their protein requirements predominantly with bushmeat from the surrounding forest. The demand for bushmeat as a source of both protein and income has increased as a result of population growth and increased economic pressures in local communities and cities (Anadu et al., 1988; Willcox \& Nambu, 2007). Despite the reported decrease in wildlife populations there has been no decrease in hunting pressure. Rather, as game species have become depleted, hunters have changed their strategies and expanded their hunting ranges, often travelling deeper into the forest to hunt (Willcox \& Nambu, 2007). Most hunters prefer to camp in the forest for several days, necessitating the use of man-made structures (bush sheds) or natural formations such as caves and rock overhangs for shelter. The use of camps as hunting bases has been identified by other studies (Noss, 1998; Muchaal \& Ngandjui, 2001; Laurance et al., 2006; Willcox \& Nambu, 2007; Rist et al., 2010; Van Vliet et al., 2010; Ofori \& Attuquayefio, 2011) and is becoming increasingly common in many countries in Sub-Saharan Africa. Circa 60\% of all hunters in Midyobo Anvom, a village in mainland Equatorial Guinea, operate from hunting camps (Rist et al., 2009). This strategy allows them to hunt in core areas of the forest far from their communities and provides them with sufficient time to hunt during both the day and night (Van Vliet et al., 2010).

The forests of Cross River are characterized by undulating mountains with steep slopes. This topography makes it difficult to construct hunting camps, and most hunters prefer to use natural formations such as caves and overhanging rocks as base camps. Most camps are used year round and in some cases from year to year, with peak use occurring in the rainy season, usually during MarchNovember (based on our personal interactions with the hunters). This corresponds to the peak breeding periods of 
the grey-necked picathartes Picathartes oreas (Awa et al., 2009), a ground-dwelling bird endemic to the equatorial tropical forest of Central and West Africa. The species is restricted to the tropical Lower Guinea forest of Nigeria, Equatorial Guinea, Congo-Brazzaville, Gabon and Cameroon, with a fragmented and declining global population estimated at 2,500-10,00o individuals (Ash, 1991; Thompson \& Fotso, 2000; Bian et al., 2006; Awa et al., 2009; BirdLife International, 2011, 2012). Ash (1991) estimated that the population in Nigeria was $500-1,000$ in the wild. However, this was probably an over-estimate (Awa et al., 2009) as it was largely based on information from hunters, who did not do counts and probably did not differentiate between active and non-active nests. Moreover, the population estimate was based on the proportion of nests collected from a single colony Ash (1991). The greynecked picathartes is categorized as Vulnerable on the IUCN Red List and listed on Appendix I of CITES (Collar \& Stuart, 1985; BirdLife International, 2011, 2012). The species breeds in mud nests constructed or renovated on overhanging rock faces, during March-November (Awa et al., 2009). Studies have attributed the decline of this species to habitat modification, predation, hunting for the bird trade and competition for nesting habitat (Ash, 1991; Thompson \& Fotso, 2000; Bian et al., 2006; Awa et al., 2009). Accidental trapping in wire snares, although not considered a significant threat, was mentioned by Awa et al. (2009) as a potential cause of population decline. We investigated the effect of hunting camps on the colonization of overhanging rocks by grey-necked picathartes in their preferred habitats, to identify human activities at breeding sites that may drive the abandonment of nests or nest sites.

\section{Study area}

Cross River contains the largest intact closed-canopy forest in Nigeria, believed to represent $>40 \%$ of the country's remaining tropical forest area (Ezebilo \& Mattsson, 2010). Located in the south-east of the country, the forests of Cross River are contiguous with those of south-west Cameroon and represent the western extension of the Cameroon Highlands (Fig. 1). The lowland rainforest habitat forms part of the hygrophilous coastal evergreen rainforest that occurs along the Gulf of Biafra. Our study area covered c. 4,00o km² and included Afi Mountain Wildlife Sanctuary, Afi River Forest Reserve, Cross River National Park, the Mbe Mountains and the Obudu Plateau (Fig. 1). The area is a biodiversity hotspot that hosts threatened primate species, including the Cross River gorilla Gorilla gorilla diehli, the Nigeria-Cameroon chimpanzee Pan troglodytes ellioti, the drill monkey Mandrillus leucophaeus, Preuss's monkey Cercopithecus preussi and Preuss's red colobus Procolobus preussi (Oates, 1999; Morgan et al., 2011), and other species of conservation importance. The forested areas are

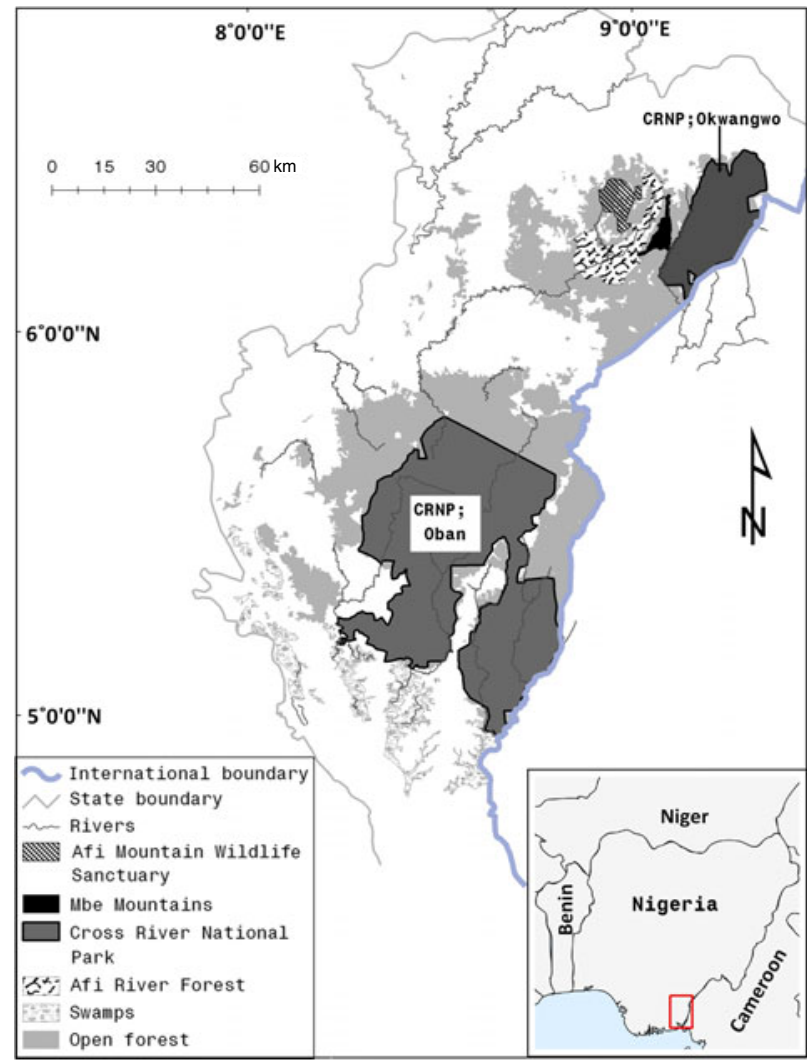

FIG. 1 Map of Cross River State, Nigeria, showing the main survey sites: Afi Mountain Wildlife Sanctuary, Afi River Forest Reserve, Cross River National Park, and the Mbe Mountains. The rectangle on the inset shows the location of the main map in south-east Nigeria.

surrounded by local communities predominantly composed of farmers, hunters and gatherers who rely heavily on forest resources for their survival (Ite \& Adams, 2000; Ezebilo \& Mattsson, 2010; Macdonald et al., 2011). Whereas hunting is carried out exclusively by men, many women and children collect non-timber forest products, including afang Gnetum africanum and bush mango Irvingia gabonensis.

\section{Method}

We searched for breeding colonies of grey-necked picathartes from August 2010 until the end of March 2011. The first phase of the survey (August-December 2010) was planned to coincide with the species' peak breeding season. We visited areas known to have grey-necked picathartes, as recorded by Ash (1991), and other areas where the species was suspected to occur. In each community we interviewed hunters and farmers. We used a conservation awareness poster, which had a clear picture of the grey-necked picathartes, to ensure that interviewees could identify the bird and its characteristic mud nest. We recruited local people with good knowledge of the survey area as paid guides. Knowing that the survey carried out by Ash (1991) 


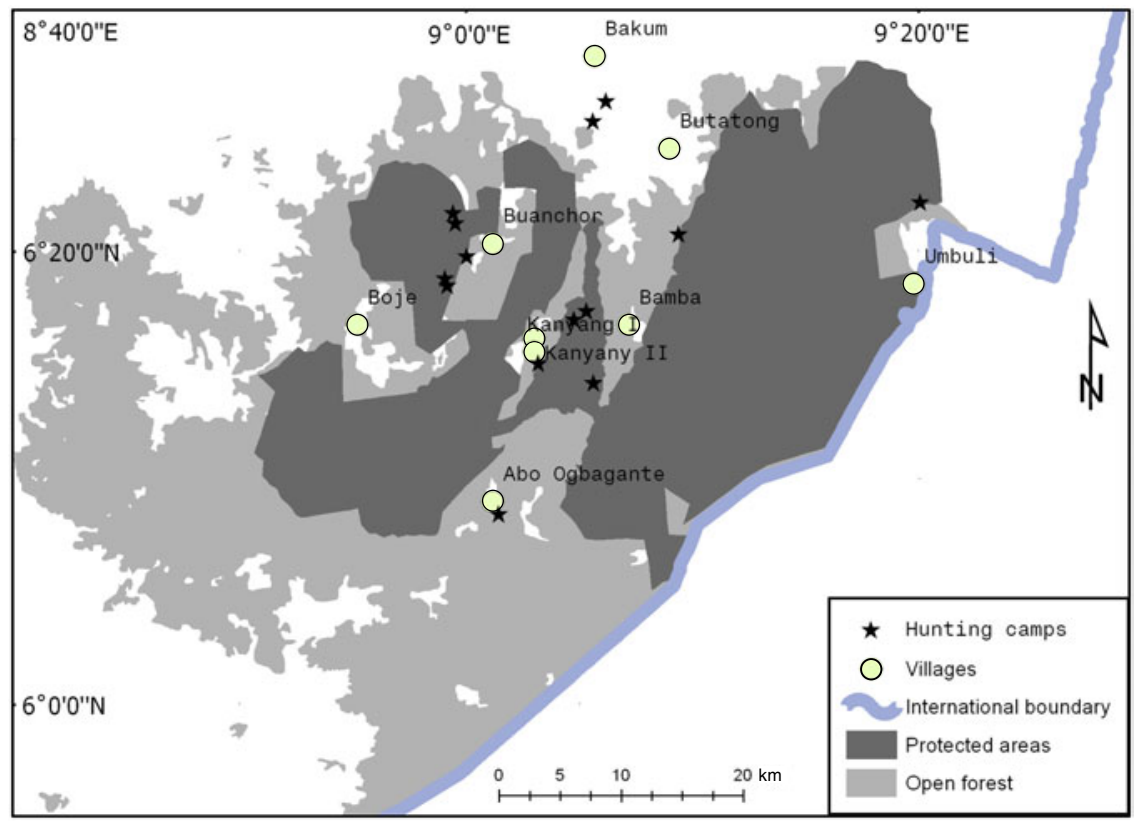

FIG. 2 Locations of hunting camps in the vicinity of the Okwangwo Division of the Cross River National Park, Afi Mountain Wildlife Sanctuary, Afi River Forest Reserve, and the Mbe Mountains (Fig. 1). was mostly based on information from local hunters and farmers, when we visited communities involved in that survey we collected information on the locations of breeding colonies from elderly hunters and farmers, some of whom had provided Ash (1991) with information on the existence of these colonies. These sites were then visited by our team and thoroughly searched for evidence of grey-necked picathartes. At each colony we recorded all evidence of camping, including sleeping beds/spots, fire stands, drying racks, wire snares, clothing, hunting bags, batteries, carbide dumps from acetylene lamps, empty cigarette packs/filters, spent cartridges, cooking utensils and feathers and other remains of animals. We assessed the effect of camping activities on the breeding colonies based on the number of dilapidated or destroyed nests and the number of breeding attempts in each colony.

\section{Data analysis}

For data analysis we used SSPS v. 20 (IBM, Armonk, USA). We used a student's $t$-test to compare the number of active nests found in hunting camps to those found in colonies with no evidence of camping. We recorded the coordinates of each colony surveyed, using a global positioning system, and used these to develop a distribution map in ArcMap v. 10 (ESRI, Redlands, USA) for all colonies disturbed by camping activities.

\section{Results}

We surveyed 84 breeding colonies (Supplementary Table S1) and identified 14 that were evidently disturbed by camping activities (Fig. 2). Only two nests in colonies used as hunting camps showed evidence of ongoing breeding attempts; one nest was under construction and one contained a single egg. We could not determine if the nest with the egg was an incomplete clutch (normal clutch size $=2$ ) or if it had been abandoned. Although we found more active nests $(1.17 \pm \mathrm{SE} 0.23, \mathrm{n}=14)$ in colonies with no evidence of camping activities than in colonies that were evidently disturbed by camping ( $0.70 \pm$ SE $0.16, n=14)$, this difference was not statistically significant. We found significantly fewer nests with evidence of ongoing or potential breeding in hunting camps $(0.14 \pm \mathrm{SE} 0.09, \mathrm{n}=14)$ than in other disturbed colonies with no evidence of camping (0.65 \pm SE 0.10, $\mathrm{n}=17, \mathrm{t}=2.2, \mathrm{P}=0.034$ ). None of the nests found on overhanging rocks or in hunting camps contained chicks. We found one nest under construction in Boje upper cave area. Fire stands were recorded at 11 of the 14 camps and were the most common evidence of camping (Supplementary Table S2). At two camps we recorded evidence of freshly destroyed nests. Two hunters in Bakum village and one in Okwa believed to camp frequently in the forest admitted to having removed chicks from a grey-necked picathartes nest some time during hunting.

\section{Discussion}

The proliferation of hunting camps and habitat modification appear to constitute the greatest threat (immediate and potential) to breeding grey-necked picathartes in southeast Nigeria. Previous studies in West and Central Africa concluded that hunting had a negligible effect on the 
declining population of picathartes in the region (Ash, 1991; Bian et al., 2006; Awa et al., 2009). However, our results indicate that the indirect effect of hunting may be more damaging than previously thought. Hunting camps are used more intensively during the rainy season (Colell et al., 1994; Muchaal \& Ngandjui, 2001), which coincides with peak breeding periods for grey-necked picathartes (Thompson \& Fotso, 2000; Harter \& Shirley, 2007; Awa et al., 2009). The intensity of hunting during the rainy season appears to be connected to availability of time more than abundance of game (hunters, pers. comm.). Most farming activities, including bush-clearing, tilling and planting, start during the dry season and continue into the early rainy season (March-April), and therefore farmers have sufficient time to hunt during the rainy season. The intensity of hunting may also be influenced by events such as the New Yam and Cassava festivals (usually August-September) and Christmas and New Year celebrations, when there is a high demand for bushmeat. Colell et al. (1994) noted that hunters in the Moka Bubis were likely to increase the frequency of hunting trips from two per week to as many as five per week during the rainy season, which also coincides with a peak in other activities that may involve camping, such as collecting bush mangos, afang and snails.

Fire stands were the most common and significant evidence of camping activities. Campers set fires for various reasons: to keep warm at night, to cook, to smoke their bushmeat catches and to deter wild animals from entering the camp. Hunters often spend several days in the forest during hunting trips (Colell et al., 1994) and therefore they need to smoke meat in the field as a form of preservation (Willcox \& Nambu, 2007). Smoked meat weighs significantly less than fresh meat, and thus smoking enables hunters to carry an increased quantity of meat (hunters, pers. comm.). It is also cost-effective because firewood is free and readily available in the forest. However, hunters do not consider their proximity to nests of breeding grey-necked picathartes when selecting sites to set fires. We noticed that areas heavily covered by soot from camp fires were often avoided by nesting birds. When present, nests in such areas were empty or dilapidated. It is likely that disturbance from heat or smoke causes breeding birds to abandon their nests. One colony appeared to have persisted at Oka Oboue (Oboue's cave) on the Bamba axis of the Mbe Mountains, where we recorded one nest with evidence of breeding. This may be a consequence of limited availability of nesting sites, with birds continuing to use preferred but disturbed rocks because no other sites are available (Thompson \& Fotso, 2000). One hunter from Bakum told us that he enjoys monitoring the nests in his hunting camp until the chicks are fully grown; he then kills the fledglings and presents the bushmeat to his children. He could not remember how many chicks he had killed or the number of times he had removed chicks from nests. A number of hunters, mostly from Belegette and Abu, confessed to removing eggs from nests while camping in breeding colonies, and three hunters from Okwangwo village had each caught at least one adult grey-necked picathartes in wire traps set around hunting camps.

Fledging success in picathartes is reportedly low. Thompson (1997) estimated that only one chick fledged for every four adult white-necked picathartes. Identified threats to breeding success include infanticide, competition for nest sites, predation and low fertility as a result of stress from disturbance (Thompson, 2004; Bian et al., 2006; Awa et al., 2009). Additional disturbances arising from camping activities and removal of eggs and fledglings from nests may have serious consequences for breeding grey-necked picathartes in the region.

The forests of south-east Nigeria, particularly in the Cross River region, are known for their critical role in conservation of threatened primates, most of which are core forest species that require dense forest vegetation. These forests are also home to a variety of bird species, including the threatened white-throated mountain babbler Kupeornis gilberti and the grey parrot Psittacus erithacus (BirdLife International, 2012). Thus management to improve the integrity of the Cross River forests by ensuring the availability of closed-canopy forests and reducing hunting activities will benefit not only grey-necked picathartes but a host of other species of conservation concern.

We therefore recommend that strict enforcement of wildlife laws and regular anti-poaching patrols will be necessary to reduce hunting pressure on the forest. During anti-poaching patrols in legally designated protected areas camping equipment found under overhanging rocks should be destroyed to discourage future camping activities. Punitive sanctions on offenders will serve as a deterrent to others with similar motives but will need to be sustained to be effective. We also advocate awareness-raising campaigns and active involvement of local people in conservation projects as necessary tools for wildlife conservation, especially for species outside protected areas.

We submitted our recommendations to the management of the Cross River National Park and the Cross River Forestry Commission (the government agency with the power to manage wildlife outside federal reserves in Cross River State). Evidence from our follow-up surveys (authors, unpubl. data) and personal discussions with the management of the National Park and NGOs working in the region suggest that there has been some improvement in protection across the protected areas in our study area. However, much still needs to be done to protect breeding colonies outside protected areas. We are collaborating with a similar project on the conservation of the Nigeria-Cameroon chimpanzee to launch a community-based outreach campaign to foster local support for the protection of breeding colonies in private lands. 


\section{Acknowledgements}

Financial support for this project was provided by the Conservation Leadership Programme through the Future Conservationist Award 2010. Additional funding for team training was provided by the Leventis Conservation Foundation. The Nigerian office of the Wildlife Conservation Society and the A.P. Leventis Ornithological Research Institute provided technical support. We are thankful to our local field assistants for their hard work during field surveys, and to the chiefs and elders of the 28 villages visited for their hospitality and for granting us permission to carry out this study.

\section{References}

Anadu, P., Elamah, P. \& Oates, J. F. (1988) The bushmeat trade in southwestern Nigeria: a case study. Human Ecology, 16, 199-208.

AsH, J. (1991) The grey-necked picathartes Picathartes oreas and Ibadan malimbe Malimbus ibadanensis in Nigeria. Bird Conservation International, 1, 93-106.

Awa, T., Dzikouk, G. \& Norris, K. (2009) Breeding distribution and population decline of globally threatened grey-necked picathartes Picathartes oreas in Mbam Minkom Mountain Forest, southern Cameroon. Bird Conservation International, 19, 254-264.

Bian, R., Awa, T., Ndang'ang'a, P., Fotso, R., Hoffmann, D. \& SANDE, E. (2006) International Species Action Plan for the Greynecked Picathartes Picathartes oreas. BirdLife International, Nairobi, Kenya and Royal Society for the Protection of Birds, Sandy, UK.

Birdife International (2011) Red List for Birds. Http://www. birdlife.org [accessed 6 June 2011].

Birdife International (2012) Species Factsheet: Picathartes oreas. Http://www.birdlife.org/datazone/speciesfactsheet.php?id=6264 [accessed 21 January 2012].

Colell, M., Maté, C. \& FA, J.E. (1994) Hunting among Moka Bubis in Bioko: dynamics of faunal exploitation at the village level. Biodiversity and Conservation, 3, 939-950.

Collar, N.J. \& Stuart, S.N. (1985) Threatened Birds of Africa and Related Islands. International Council for Bird Preservation, Cambridge, UK.

Cordeiro, N.J., Burgess, N.D., Dovie, D.B., Kaplin, B.A., Plumptre, A.J. \& Marrs, R. (2007) Conservation in areas of high population density in sub-Saharan Africa. Biological Conservation, $134,155-163$.

Ezebilo, E.E. \& Mattsson, L. (2010) Socio-economic benefits of protected areas as perceived by local people around Cross River National Park, Nigeria. Forest Policy and Economics, 12, 189-193.

Harter, B.B. \& Shirley, M.H. (2007) Notes on breeding and conservation of the grey-necked picathartes Picathartes oreas in mainland Equatorial Guinea. Ostrich: Journal of African Ornithology, 78, 97-100.

Ite, U. \& AdAms, W. (2000) Expectations, impacts and attitudes: conservation and development in Cross River National Park, Nigeria. Journal of International Development, 12, 325-342.

Laurance, W.F., Croes, B.M., Tchignoumba, L., Lahm, S.A., Alonso, A., Lee, M.E. et al. (2006) Impacts of roads and hunting on central African rainforest mammals. Conservation Biology, 20, 1251-1261.
Macdonald, D.W., Johnson, P.J., Albrechtsen, L., Dutton, A., Seymour, S., Dupain, J. et al. (2011) Association of body mass with price of bushmeat in Nigeria and Cameroon. Conservation Biology, 25, 1220-1228.

Morgan, B., Adeleke, A., Bassey, T., Bergl, R., Dunn, A., Gadsby, E. et al. (2011) Regional Action Plan for the Conservation of the Nigeria-Cameroon Chimpanzee (Pan troglodytes ellioti). IUCN/ SSC Primate Specialist Group and Conservation Zoological Society of San Diego, San Diego, USA.

MuchaAl, P.K. \& NGandjui, G. (2001) Impact of village hunting on wildlife populations in the western Dja Reserve, Cameroon. Conservation Biology, 13, 385-396.

Noss, A.J. (1998) The impacts of cable snare hunting on wildlife populations in the forests of the Central African Republic. Conservation Biology, 12, 390-398.

OAtes, J.F. (1999) Myth and Reality in the Rain Forest: How Conservation Strategies are Failing in West Africa. University of California Press, Berkely, USA.

Ofori, B. \& Attuquayefio, D. (2011) Hunting intensity in the Suhuma Forest Reserve in the Sefwi Wiawso district of the Western Region of Ghana: a threat to biodiversity conservation. West African Journal of Applied Ecology, 17, 135-142.

Rist, J., Milner-Gulland, E.J., Cowlishaw, G. \& Rowcliffe, J.M. (2009) The importance of hunting and habitat in determining the abundance of tropical forest species in equatorial Guinea. Biotropica, 41, 700-710.

Rist, J., Milner-Gulland, E., Cowlishaw, G. \& Rowcliffe, M. (2010) Hunter reporting of catch per unit effort as a monitoring tool in a bushmeat-harvesting system. Conservation Biology, 24, 489-499.

ThOMPSON, H.S. (1997) The breeding biology and ecology of the white-necked picathartes (Picathartes gymnocephalus) Temminck 1825, in Sierra Leone. PhD thesis. Open University, Milton Keynes, UK.

Thompson, H.S. (2004) The reproductive biology of the white-necked picathartes Picathartes gymnocephalus. Ibis, 146, 615-622.

Thompson, H.S. \& Fotso, R. (2000) Conservation of two threatened species: Picathartes. Ostrich, 71, 154-156.

Van Vliet, N., Milner-Gulland, E., Bousquet, F., Saqalli, M. \& NASI, R. (2010) Effect of small-scale heterogeneity of prey and hunter distributions on the sustainability of bushmeat hunting. Conservation Biology, 24, 1327-1337.

Wilkie, D.S. \& Carpenter, J.F. (1999) Bushmeat hunting in the Congo Basin: an assessment of impacts and options for mitigation. Biodiversity and Conservation, 8, 927-955.

Willcox, A.S. \& NambU, D.M. (2007) Wildlife hunting practices and bushmeat dynamics of the Banyangi and Mbo people of Southwestern Cameroon. Biological Conservation, 134, 251-261.

\section{Biographical sketches}

Fidelis Atuo has worked on the conservation of threatened avian and primate species in the tropical rainforest of Nigeria for over 5 years. His current research is focused on the non-lethal effect of the presence of predators on the available space for prey species. Samuel IVAnde's research interests lie in the distribution and migration ecology of birds, conservation of tropical birds, and citizen participation in conservation science. ZINGFA WALA's research is focused on understanding the influence of climate change on geographical ranges and distribution dynamics of biodiversity. Timothy O'Connell's research focuses on habitat relationships and distributions of birds. 